\title{
Northern range edge equilibrium of Ambrosia artemisiifolia L. not achieved in Western Europe
}

\author{
William Ortmans, Grégory Mahy, Arnaud Monty
}

University of Liège - Gembloux Agro-Bio Tech. BIOSE department. Biodiversity and Landscape Unit. Passage des Déportés, 2. BE-5030 Gembloux (Belgium). E-mail: ortmans.w@gmail.com

Received on June 16, 2016; accepted on February 21, 2017.

This article is distributed under the terms and conditions of the CC-BY License (http://creativecommons.org/licenses/by/4.0)

Description of the subject. The geographic distributions of a species, be it native or alien, is expected to be limited at some point by environmental conditions. In this situation, a range edge equilibrium (REE) takes place, i.e., populations occurring beyond the edge have a growth rate reduced below replacement. The occurrence of REE has never been tested for an invasive species. In Western Europe, the invasive weed Ambrosia artemisiifolia L. has spread in most parts of southern and central France, where it can be found in very high densities in sunflower fields, but seems to be limited in its northwards expansion. It is currently unknown whether the range has reached a limit or not. Information about how the species responds to sunflower competition is also lacking.

Objectives. This work addressed two questions: Has the northern part of A. artemisiifolia invaded range in Western Europe reached REE? How is A. artemisiifolia performance influenced by sunflower competition?

Method. Plots were established in an agricultural field ca. $250 \mathrm{~km}$ north to the current invaded range, in Belgium. We planted A. artemisiifolia seedlings with or without sunflower competition. The following year, the population growth rates and the soil seed bank were assessed.

Results. The species established populations with relatively high growth rates and soil seed bank. Sunflower competition did not have a significant impact on plant performance.

Conclusions. The results invalidate the hypothesis of equilibrium at the current margin of A. artemisiifolia invaded range, and suggest a significant potential for invasion northwards.

Keywords. Geographical distribution, invasive species, interspecific competition, field experimentation, ecological factors, Helianthus annuиs, Belgium.

L'équilibre en bordure d'aire nord n'est pas atteint pour l'invasion d'Ambrosia artemisiifolia L. en Europe de l'Ouest Description du sujet. La distribution géographique d'une espèce, indigène ou invasive, peut être limitée par l'environnement. Dans cette situation, le taux de croissance des populations au-delà de la bordure d'aire est inférieur au taux de remplacement, et un équilibre en bordure d'aire (Range edge equilibrium, REE) prend place. L'émergence d'un REE n'a jamais été spécifiquement testée chez une espèce invasive. En Europe de l'Ouest, l'espèce invasive Ambrosia artemisiifolia L. est très abondante dans les champs de tournesols du centre et du sud de la France, mais sa progression semble limitée vers le Nord. Actuellement, on ne sait pas si l'espèce a atteint un REE ou non. Des informations sur la réponse de l'espèce face à la compétition du tournesol sont également manquantes.

Objectifs. Ce travail adresse deux questions : En Europe de l'Ouest, A. artemisiifolia a-t-elle atteint un REE au nord de son aire d'invasion? Comment la compétition du tournesol influence-t-elle l'espèce?

Méthode. Des plantules d'A.artemisiifolia ont été plantées avec ou sans tournesols dans des quadrats installés dans un champen Belgique, environ $250 \mathrm{~km}$ au nord du front d'invasion. L'année suivante, le taux de croissance des populations et la banque de graines ont été évalués.

Résultats. Le taux de croissance des populations et la banque de graines ont été relativement importants. La compétition du tournesol n'a pas eu d'impact significatif sur les performances des plants.

Conclusions. Les résultats réfutent l'hypothèse d'un équilibre au front d'invasion actuel et suggèrent un potentiel d'invasion significatif vers le Nord.

Mots-clés. Distribution géographique, espèce envahissante, compétition interspécifique, expérimentation au champ, facteur écologique, Helianthus annuиs, Belgique. 


\section{INTRODUCTION}

Species distributions are essentially the expression of a species' ecological niche in space (Sexton et al., 2009). At the range edge of a given species, further expansion of the range is limited by biotic or abiotic factors that impede new populations' survival beyond the edge (Hutchinson, 1957). Despite some minor fluctuations due to temporal variability at the range edge (Sexton et al., 2009), the long-term distribution of most native species is stable, and the situation is described as being in a range edge equilibrium (REE) (Stanton-Geddes et al., 2012).

Biological invasions consist of the spread of invasive alien species in a new range, where they historically have not been present (Mack, 1981). At first, this new range is expanding with the species colonizing new habitats (Monty \& Mahy, 2009; Alexander \& Edwards, 2010). But all species are limited at some point along environmental gradients in their introduced range, just as they are in their native range (Alexander \& Edwards, 2010). Due to the damage that invasive species can cause, it is important to predict how far their range might expand. Species' range limits are well-known for native species (Stanton-Geddes et al., 2012; Hargreaves et al., 2014), and there is increasing evidence of range limits for alien species (Sexton et al., 2009; Alexander \& Edwards, 2010). However, as is best presently known, no studies have explicitly tested REE for invasive species. This test would allow determination of whether the invasion range may or may not expand further.

The population growth rate is the rate at which the number of individuals in a population changes in a given time period. It informs on whether the number of individuals is increasing, stable or decreasing, and how fast it is changing. Conventionally, the factor by which population size increases per year is the finite growth rate, and is given the symbol $\lambda$. It is calculated as $\mathrm{N}_{\mathrm{t}+1} / \mathrm{N}_{\mathrm{t}}$ (Sibly \& Hone, 2002), where $\mathrm{N}$ is the number of individuals, and $t$ and $t+1$ are two given consecutive years. The measurement of $\lambda$ beyond the range edge can be used to test the hypothesis of a REE (StantonGeddes et al., 2012; Hargreaves et al., 2014). Finding that $\lambda$ is reduced below replacement $(\lambda<1)$ beyond the edge would indicate that the species distribution is stable. Occurrences of a population beyond the edge do not automatically disprove REE. For example, casual populations may persist several years despite unsuitable environmental conditions that limit their reproduction. The occurrence of such populations can be attributable to repeated introductions by human activity (Richardson et al., 2000), or to the formation of a soil seed bank that recovers the population, e.g., after a disturbance event (Gioria et al., 2012).

Ambrosia artemisiifolia L. (Common ragweed, Asteraceae) is an annual invasive weed that was introduced from North America to Europe more than a century ago (Heckel, 1906). The species is currently invading numerous European countries (Chauvel et al., 2006; Kazinczi et al., 2008; Smith et al., 2013), where it is causing a health crisis because of its allergenic pollen (Kazinczi et al., 2008; Smith et al., 2013). The invasion is mostly favored by human activity and mostly grows along roads, riverbanks, wastelands and cultivated fields (Bassett \& Crompton, 1975). Because the sunflower and A. artemisiifolia are both from the Asteraceae family, chemical control of the species is often ineffective (Chollet et al., 1999). Despite the fact that some sunflower varieties (e.g. Clearfield, Express Sun) tolerate some herbicide application and therefore facilitate the chemical treatment of A.artemisiifolia, high densities of the plant can often be observed in sunflower fields (Genton et al., 2005; Fumanal et al., 2008a; Pinke et al., 2013).

The species can show considerable phenotypic variation, both in terms of plant size (Leiblein-Wild \& Tackenberg, 2014; Ortmans et al., 2016a) and seed traits (Fumanal et al., 2007a; Ortmans et al., 2016b). Plant height can vary from 0.1 to $2.5 \mathrm{~m}$ according to environmental conditions (Essl et al., 2015). A single plant can produce from 300 to 6,000 seeds on average, and this number can reach 14,000 when the conditions are favorable (Bassett \& Crompton, 1975). In addition, the species lifecycle is characterized by a long-term persisting seedbank (Bassett \& Crompton, 1975; Fumanal et al., 2008b) that appears to play a major role in the invasion process (Baskin \& Baskin, 1980; Guillemin \& Chauvel, 2011). This is especially problematic in cultivated fields, where the seeds are buried or recovered when the ground is plowed (Bassett \& Crompton, 1975; Baskin \& Baskin, 1980; Fumanal et al., 2008b; Guillemin \& Chauvel, 2011; Gioria et al., 2012).

In Europe, its invasive range is intensively studied (Chauvel et al., 2006; Kazinczi et al., 2008; Essl et al., 2009; Pinke et al., 2011; Skjøth et al., 2013; Smith et al., 2013; Essl et al., 2015; Ortmans et al., 2016a). Currently, there are three main regions that are highly invaded in Europe (Skjøth et al., 2013; Smith et al., 2013; Essl et al., 2015): the southeast of France (the Rhône Valley; Chauvel et al., 2006), the north of Italy (the Po region) and a larger area including western Austria (Essl et al., 2009), southern Czech Republic, southern Poland, Slovakia, Hungary (Kazinczi et al., 2008; Pinke et al., 2011), Slovenia, Croatia, Bosnia and Herzegovina, Serbia, Ukraine, and Romania.

North of these highly invaded areas, the species is also present in lower densities. The invasion has reached northern France, northeast Germany, northern Poland, the Belarus and Russia. For the moment, it is difficult to predict how far the invasion will extend. The distribution of A.artemisiifolia appears to be limited 
in Northern Europe by low autumnal temperature that kills the adult plants before seed production (Chapman et al., 2014; Skálová et al., 2015).

In Western Europe, some populations have been recorded over the years in Belgium, The Netherlands and northern Germany. However, these populations do not appear to become invasive (Verloove, 2006; Brandes \& Nitzsche, 2007; Martin \& Lambinon, 2008). Based on the literature and pollen density maps (Skjøth et al., 2013; Smith et al., 2013) it is possible to approximately map the invaded range in Western Europe (Figure 1). Furthermore, in Belgium, A.artemisiifolia is still

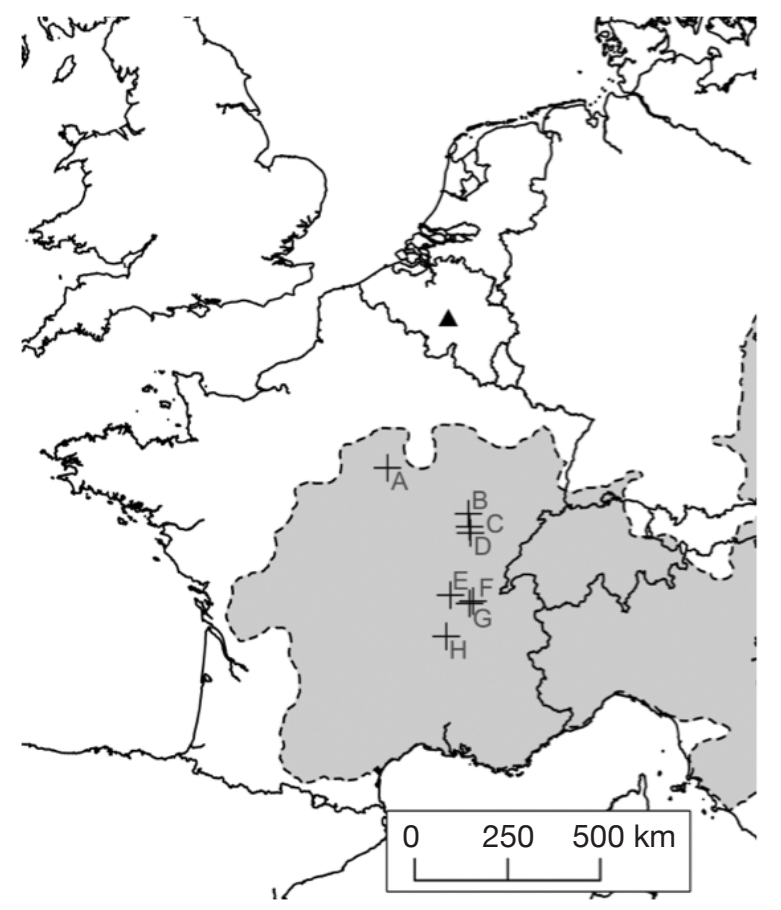

Figure 1. Locations of the eight Ambrosia artemisiifolia L. sampled populations in France - Localisation des huit populations d'Ambrosia artemisiifolia échantillonnées en France.

The cross symbols indicate populations' location. The capital letters indicate the population ID. The plain triangle is the field experiment location. The gray surface with a dashed outline is the area where A. artemisiifolia pollen density is above 100 pollen grains $\cdot \mathrm{m}^{-3} \cdot \mathrm{year}^{-1}$, and is considered as the current invaded range (adapted from the pollen map in Smith et al., 2013 from Skjøth et al., 2013) - Les symboles en croix indiquent l'emplacement des populations. Les lettres majuscules renseignent le code des populations. Le triangle plein montre l'emplacement du jardin expérimental. La surface grise disposant d'un contour discontinu représente la zone où la densité de pollen d'A. artemisiifolia est supérieure à 100 grains $\cdot m^{-3} \cdot a n^{-1}$. Cette surface est considérée comme l'aire d'invasion actuelle (adaptée de la carte pollinique dans Smith et al., 2013 d'après Skjøth et al., 2013). considered a casual non-naturalized species, because the local climate is described as limiting the plant's development (Lambinon et al., 2004; Verloove, 2006; Martin \& Lambinon, 2008). In contrast, several authors have predicted that the species will probably increase its distribution northwards (Cunze et al., 2013; Chapman et al., 2014; Storkey et al., 2014; LeibleinWild et al., 2016). This situation leads to questions about whether the invasion will indeed stabilize. Given that A.artemisiifolia is highly detrimental to humans (Kazinczi et al., 2008; Smith et al., 2013), there is an urgent need to determine if the invaded range will expand or not.

The species' invasion appears to be linked to sunflower cultivation (Chollet et al., 1998; Genton et al., 2005; Fumanal et al., 2008a; Pinke et al., 2013; Ozaslan et al., 2016). Sunflower production could be one of the factors behind the success of the invasion, and studies aiming to understand how $A$. artemisiifolia thrives in agricultural habitats are therefore needed (Pinke et al., 2013; Ozaslan et al., 2016). In sunflower fields, the competition inflicted on weed species is not expected to be homogeneous all over the field. For example, in field margins, the sunflower densities could be reduced due to an edge effect (Sosnoskie et al., 2007). Furthermore, field margins are known to harbor more weeds and pest species than the rest of the field, and can serve as a stepping stone for the invasion of the center of the field or as a source population for the invasion of adjacent fields (Blumenthal \& Jordan, 2001; Sosnoskie et al., 2007). In order to assess how sunflower competition can impact A.artemisiifolia, this factor was explicitly tested in our study.

Specifically, the work presented here addressed the following questions:

- Has the distribution of A. artemisiifolia in Western Europe reached a REE situation?

- How is A. artemisiifolia performance influenced by sunflower competition?

To answer these questions, a field experiment was established $250 \mathrm{~km}$ north of the current margin of the invaded range in Western Europe. There have been many occurrences of the species close to the study site (Bullock et al., 2012; Ortmans et al., 2016a), so this experiment does not risk introducing the species into a virgin territory. The experimental context was a sunflower field. Ambrosia artemisiifolia plants from eight different populations from France were left to grow and reproduce, with or without sunflower competition. To take into account the variation induced by the origin of the population, this factor was explicitly introduced into the analysis. After two growing seasons, and before the second seed rain, population finite growth rates were assessed, and the soil seed bank was quantified. 


\section{MATERIALS AND METHODS}

\subsection{Seed collection}

The seeds were collected in the nearest invaded area from Belgium, in France. The seed collection occurred in the autumn 2011 in eight populations (Figure 1). A population was defined as a set of individuals of the same species growing on a uniform landscape element, at a given moment. Populations' habitat was either ruderal (riverbank, railroad, soil deposit) or agricultural (corn field, uncultivated field, and fallows). The seed collection was carried out on 20 to 40 plants by population, and the collected seeds were pooled by population. The seeds were stored in cold $\left(5^{\circ} \mathrm{C}\right)$ and dry conditions.

\subsection{Experimental design}

Prior to the start of the experiment, circa 150 seeds per population were stratified for 6 weeks at $5{ }^{\circ} \mathrm{C}$ on wet paper filter. Then the seeds were sown in plastic trays containing a thin layer of moisturized soil from the study site. Trays were put in a greenhouse in order to induce germination, but without supplementary heating, ventilation or lightning. On the $1^{\text {st }}$ of May 2013, we selected 48 seedlings at the same development stage (i.e., with only cotyledons) of each population to be transplanted into the field experiment.

The field experiment was established approximatively $250 \mathrm{~km}$ north of the current invasion range, in Gembloux, Belgium $\left(50.565^{\circ} \mathrm{N}\right.$ latitude, $4.703^{\circ} \mathrm{E}$ longitude). The experiment was established in an open ground agricultural field that served as a fallow land for several years. The soil is mainly loamy, with a share of sand and a small part of clay, fairly rich and favorably drained. To mimic the agricultural conditions, a plowing followed by tillage was performed. We established 64 plots of $1.4 \times 1.4 \mathrm{~m}\left(1.96 \mathrm{~m}^{2}\right)$ following a grid, and we spaced each plot $30 \mathrm{~cm}$ away from one another. Each plot was randomly assigned to one of the eight populations (A to $\mathrm{H}$ ), and six seedlings of that population were planted. We paid attention to plant each plant at least $35 \mathrm{~cm}$ from one another, and at least $40 \mathrm{~cm}$ away from a border, to avoid future seeds falling off the plot during the fruiting season.

Four plots of each population (i.e., half the plots) were randomly selected to receive the sunflower competition. This competition was applied following the agricultural technical itinerary available on the website of the French Technical Institute for oilseeds, protein crops, and hemp and their chains (Cetiom, 2013). This itinerary informs about the density and spacing of sunflower rows used in French agriculture (i.e., a density of six sunflowers by square meter and a spacing of $50 \mathrm{~cm}$ between rows). Thus, on the $1^{\text {st }}$ of May 2013, we sowed 12 sunflowers on three equidistant rows spaced by $50 \mathrm{~cm}$ in each plot, with the center row aligned to the middle of the plot. On the $1^{\text {st }}$ of June 2013, we performed a second sowing to replace the dead sunflowers. Every two weeks, new weeds other than ragweed seedlings were pulled up by hand to imitate the low competition normally occurring in sunflower crops.

On the first flower appearance, i.e., on the $31^{\text {st }}$ of July 2013 a wood frame supporting a "pollen-proof" small mesh fabric (Plantex ${ }^{\circledR}$ Protectmax, Du Pont de Nemours, Puteaux, France) was installed above each plot. This fabric allowed water to flow but limited pollen dispersion. The aim of this installation was to reduce cross fertilization among populations, and the hazard that the pollen can cause to the nearby inhabitants. To avoid inducing too much changes in environmental conditions, e.g., a decrease in the light received by the plants, or an increase in temperature within the frame, the fabric was only fixed until the $31^{\text {st }}$ of September 2013. To prevent this experiment from acting as a source population, or from being a new introduction focus, we took caution to limit seed dispersal. We installed a fence on the ground that delimitated each plot, consisting of a $2 \mathrm{~mm}$ mesh of $30 \mathrm{~cm}$ height, with the bottom $10 \mathrm{~cm}$ buried in the soil. This fence allowed the water to flow but prevented the released seeds from being carried away by runoff water.

In the second growing year, on the $3^{\text {rd }}$ of March 2014, we mimicked tillage by scratching the soil surface with a rake. On A. artemisiifolia seedlings' first emergence, on the $27^{\text {th }}$ of March 2014, we sowed once again sunflowers following the same protocol. The sowing occurred on the same plots as the previous year, to perpetuate the sunflower competition.

Following the end of the experiment, all the remaining plants were hand pulled to avoid creating a new population at the experimental site. We did not plow the field, in order to avoid burying seeds that can therefore remain viable a long time (Baskin \& Baskin, 1980). We then realized a stale seedbed to deplete the soil seedbank, and then we established a pasture that applies sufficient competition to limit the development of the plant. The pasture is monitored regularly and the new A. artemisiifolia plants are hand pulled.

\subsection{Plant performance measurements}

In order to obtain a non-destructive measurement of the plant performance at the end of the first year, we measured the height and diameter of all the A. artemisiifolia plants on the $1^{\text {st }}$ of October 2013. Then, we calculated a mean biovolume by plot as:

$$
\text { Biovolume }=\frac{1}{k} \sum_{i=1}^{k}\left[\pi\left(\frac{D_{k}}{2}\right)^{2} H_{k}\right]
$$


where $k$ is the number of plants within the plot, and $D$ and $H$, respectively, the diameter and height. Biovolume is a non-destructive measurement that is highly correlated to the biomass (Sarmiento et al., 2012), and is therefore a useful measurement to take for the comparison of population growth performance.

We let the plants produce and release seeds. Since the species has barochoric dispersal, we assumed that the large majority of the seeds fell within the plot.

On the $14^{\text {th }}$ of February 2014, the plants completely lost their seeds and leaves, and had the appearance of dead branches. At that moment, we cut the stems at the ground surface and removed them, in order to allow the monitoring of the plots, the mimicked tillage operation, the sunflower sowing, and the other weed species removal.

The second year, on the $1^{\text {st }}$ of August 2014, we counted the number of plants in each plot by a subsampling method. The subsamples consisted of three randomly placed frames of $290 \mathrm{~cm}^{2}$ within the plot. The total number of offspring by plot was then assessed. We also calculated $\lambda$ (i.e., the population finite growth rate of each plot) by dividing the assessed number of offspring in August 2014 by six (the number of transplanted parents in 2013). On the same date, the stems of all plants were cut at the ground surface and were paper bagged by plot. The paper bags were dried for four days at $80^{\circ} \mathrm{C}$ then weighted to the nearest $1 \mathrm{~g}$ (Optiss BC5000V1, Tefal, Sarcelles, France) to determine the offspring biomass. The biomass of A. artemisiifolia is closely related to the quantity of pollen and seeds produced by the plant (Fumanal et al., 2007b), and is thus a proxy for the reproductive performance. Finally, to evaluate how a single seed rain can contribute to the population growth, we made an evaluation of the soil seed bank. Twenty carrots of $2 \mathrm{~cm}$ diameter and $10 \mathrm{~cm}$ depth were sampled randomly at the surface of each plot. The carrots were plastic bagged, moistened, and then stratified for 6 weeks at $5^{\circ} \mathrm{C}$. After the stratification, the soil in the bags was spread in a thin layer within $15.1 \times 20.2 \mathrm{~cm}$ aluminum trays and the seeds were allowed to germinate in a heated greenhouse. The temperature was always above $15^{\circ} \mathrm{C}$, and we applied a photoperiod of $18 \mathrm{~h}$ per day $/ 6 \mathrm{~h}$ per night. The trays were watered every 3 days to allow the germination. The germinations were recorded and snatched weekly during 16 weeks. The germination record stopped when no germination had occurred for 2 weeks. The dormant soil seed bank is thus assessed as the total number of germinations.

\subsection{Climatic data}

In order to compare the weather that occurred during the two experimental years, the regional climate, annual mean temperature and precipitation data since 1998 were acquired on the website of the Royal Meteorological Institute of Belgium (2015). The weather station, which recorded the data, is located in Uccle, Belgium, and is representative of the regional climate occurring at the study site.

\subsection{Statistical analysis}

The variations of the plant performance-related traits were analyzed with descriptive statistics (mean, standard error of the mean, minimum, and maximum). To explore the effect of the population and competition on plant performance, we used a mixed model analysis of variance (ANOVA). We included the competition as a fixed effect, and population as a random effect. The interaction between population and competition was included in the model. No variable transformation improved the homoscedasticity of the data. All statistical analyses were performed with Minitab ${ }^{\circledR}$ ver. 16.2.2 (Minitab Inc., State College, PA, USA).

\section{RESULTS}

The biovolume of the parent plants was very variable and ranged from $0.232 \mathrm{~m}^{3}$ to $2.630 \mathrm{~m}^{3}$. The offspring number was very superior to the number of parents, and varied from 431 to 4,789 , depending on the plot. The $\lambda$ by plot averaged 273 . The offspring biomass by plot averaged $656 \mathrm{~g}$. The dormant soil seed bank was lower than the number of offspring, but still averaged 306 seeds $\cdot \mathrm{m}^{-2}$ by plots. The complete descriptive statistics are given in table $\mathbf{1}$.

The results of the two-way ANOVAs showed that the competition exerted by sunflowers had a significant influence on the biovolume, but did not have a significant impact on the variables measured during the second growing year (i.e., offspring number, $\lambda$, offspring biomass, and dormant soil seed bank; Table 2). The populations only varied in terms of dormant soil seed bank (Table 2). The interaction between population and the competition was not significant for any response variable. The offspring biomass and the $\lambda$ were not significantly influenced by the studied factors (Table 2 ). To represent the variation among the population of the measured trait for which a significant variation was found, bar graphs were drawn (Figure 2).

The regional climatic data showed that the two considered years were different from the average temperature and precipitations that occurred over the last 15 years (Figure 3). The 2013 growing year was colder $\left(10.1^{\circ} \mathrm{C}\right)$ than the mean temperature between 1998 and $2012\left(11.0 \pm 0.121^{\circ} \mathrm{C}\right)$. Conversely, 2014 was warmer $\left(11.9^{\circ} \mathrm{C}\right)$ than the average. Both years were drier ( $816 \mathrm{~mm}$ and $784 \mathrm{~mm}$, respectively) than the average $(882 \pm 29.3 \mathrm{~mm})$. 
Table 1. Means, standard errors of the mean (SE), minimum and maximum of the measured plant performance-related traits - Moyennes, erreurs standard de la moyenne, minimum et maximum des traits liés aux performances.

\begin{tabular}{lllll}
\hline Variable & Mean & SE mean & Minimum & Maximum \\
\hline Biovolume $\left(\mathrm{m}^{3}\right)$ & 1.09 & 0.0592 & 0.232 & 2.36 \\
Offspring number & 1,635 & 111 & 431 & 4,789 \\
Population finite growth rate & 273 & 18.4 & 72 & 798 \\
Offspring biomass $(\mathrm{g})$ & 656 & 27.7 & 253 & 1,289 \\
Dormant soil seed bank $\left(\right.$ seeds $\left.\cdot \mathrm{m}^{-2}\right)$ & 306 & 50.7 & 0 & 2,069 \\
\hline
\end{tabular}

Table 2. Results of the ANOVA performed to test the influence of the population, the competition, and the interaction of these parameters on the plants' performance - Résultats de l'ANOVA réalisée afin de tester l'influence de la population, de la compétition et de l'interaction entre ces deux paramètres sur les performances des plants.

\begin{tabular}{|c|c|c|c|c|c|c|c|c|c|c|c|}
\hline \multirow[t]{2}{*}{ Source of variation } & \multirow[t]{2}{*}{ df } & \multicolumn{2}{|c|}{ Biovolume } & \multicolumn{2}{|c|}{ Offspring number } & \multicolumn{2}{|l|}{$\lambda$} & \multicolumn{2}{|c|}{ Offspring biomass } & \multicolumn{2}{|c|}{ Dormant SSB } \\
\hline & & $\overline{\mathbf{F}}$ & $\mathbf{P}$ & $\mathbf{F}$ & $\mathbf{P}$ & $\mathbf{F}$ & $\mathbf{P}$ & $\mathbf{F}$ & $\mathbf{P}$ & $\mathbf{F}$ & $\mathbf{P}$ \\
\hline Population & 7 & 2.93 & 0.090 & 3.73 & 0.052 & 3.73 & 0.052 & 1.86 & 0.215 & 12.17 & 0.002 \\
\hline Competition & 1 & 17.07 & 0.004 & 1.90 & 0.211 & 1.90 & 0.211 & 1.14 & 0.322 & 0.09 & 0.778 \\
\hline Pop. ${ }^{*}$ Comp. & 7 & 0.96 & 0.471 & 0.98 & 0.460 & 0.98 & 0.460 & 1.07 & 0.397 & 0.31 & 0.948 \\
\hline
\end{tabular}

$\lambda$ : population finite growth rate - taux de croissance fini des populations; SSB: soil seed bank - banque de graine du sol; bold values are significant - les valeurs en gras sont significatives.
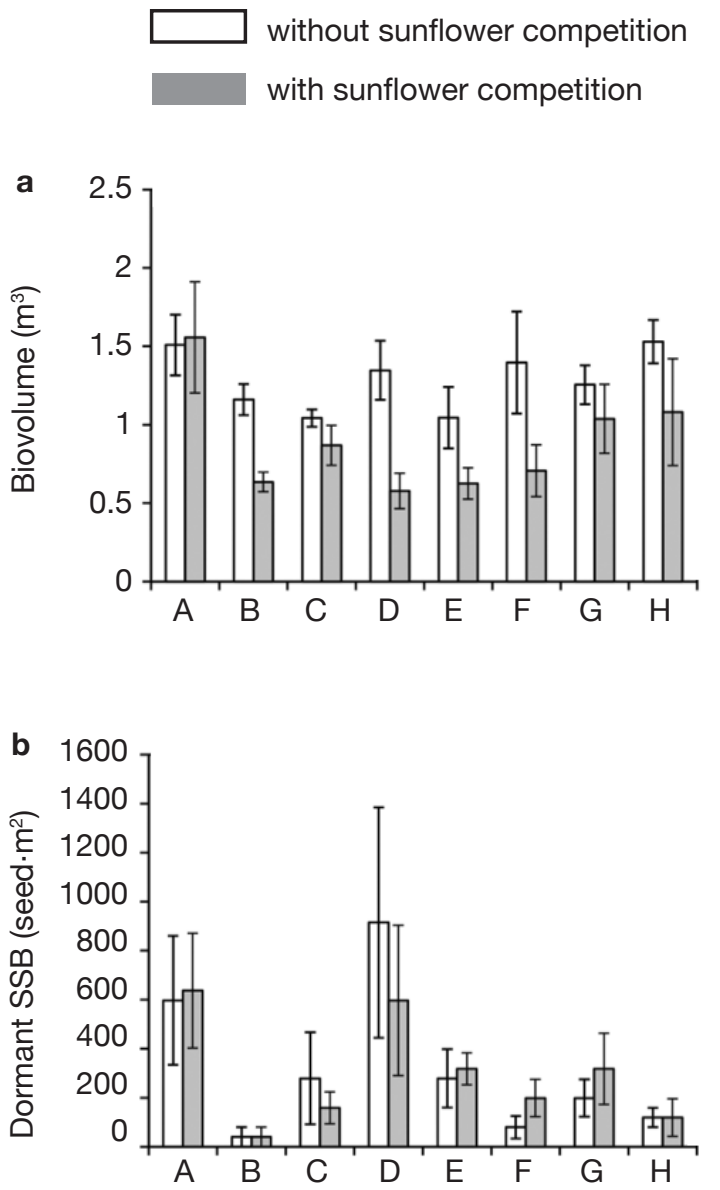

Figure 2. Bar graphs showing means and standard errors of biovolume (a) and dormant soil seed bank (b) of Ambrosia artemisiifolia L. experimental populations - Graphiques montrant les moyennes et l'erreur standard sur la moyenne du biovolume (a) et de la banque de graine dormante $(\boldsymbol{b})$ des populations expérimentales d'A. artemisiifolia.

White colored bars represent the plots without sunflower competition, and grey colored bars the plots with sunflower competition. The graphs represent every measured trait for which significant differences have been observed among populations, or competition treatment, using the ANOVA - Les rectangles blancs représentent les quadrats sans compétition en tournesol, et les rectangles gris les quadrats avec une compétition en tournesol. Les graphiques représentent les traits pour lesquels des variations significatives ont été observées entre populations ou entre niveaux de compétition, d'après les résultats de l'ANOVA.

\section{DISCUSSION}

This experiment showed that $A$. artemisiifolia is able to develop populations with a $\lambda$ significantly greater than 1 in agricultural conditions beyond its current invaded range. The hypothesis of equilibrium at the edge of the current invaded range is thus rejected.

The processes that can limit the range expansion of an invasive species can be multiple (e.g., genetic constraints that impede local adaptation, too harsh environmental conditions that limit population growth, ordispersal limitations to suitable sites) (Monty \& Mahy, 


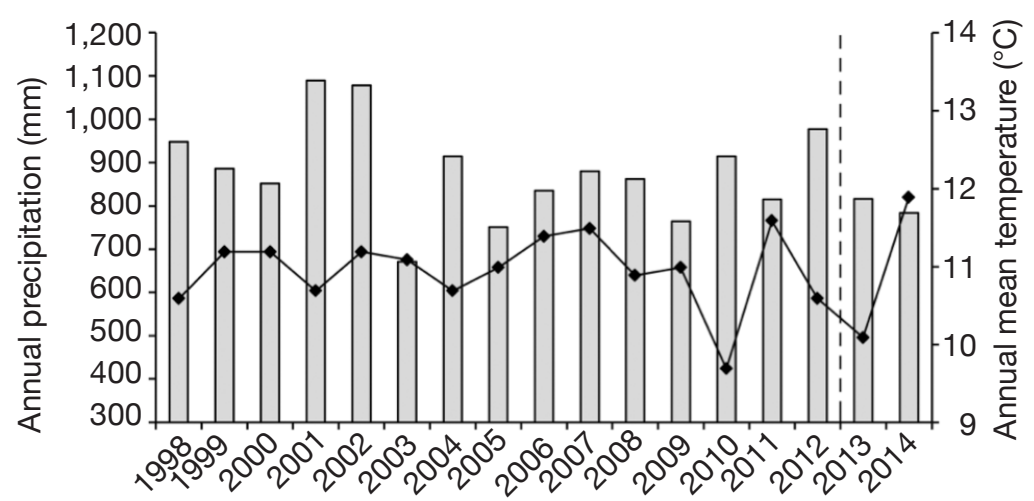

Figure 3. Diagram of the annual precipitations and mean temperature, used to contextualize the weather conditions experienced in 2013 and 2014, over the last 15 years - Diagramme des précipitations annuelles et des moyennes de températures utilisées afin de contextualiser les conditions météorologiques observées en 2013 et 2014 avec les conditions des 15 années précédentes.

The annual precipitations are represented by the gray bars (left vertical axis) and the mean annual temperatures by the square symbols on the black line (right vertical axis). The dashes separate the two years studied from the years shown for comparison - Les précipitations annuelles sont représentées à l'aide des rectangles gris (axe vertical gauche) et les moyennes de températures à l'aide des losanges et de la ligne noirs (axe vertical droit). La ligne segmentée sépare les années étudiées des années montrées dans un but de comparaison. reported as a result of the modification of agricultural practices. For example, the archeophyt weeds followed the culturing of cereals from the Middle East to Europe, thereby increasing greatly their invaded range (Fried et al., 2009).

The sunflower competition impacted significantly the biovolume of the parent plant, but this factor did not have an impact the following year: the offspring biomass, the soil seed bank, and the lambda were left unaltered. This observation suggests that, despite a sensibility to interspecific competition (Leskovšek et al., 2012), the sunflower appears to be a poor competitor against A.artemisiifolia. The large spacing between the sunflower plants makes this kind of crop especially invasible by A.artemisiifolia. Since its development is relatively synchronized with the sunflower, the use of fertilizer or the suppression of the other weeds could also benefit A.artemisiifolia, and therefore increase the invasibility of this type of crop. Given the poor effect of the sunflower competition, the facilitation effect of field margin situations is probably of minor importance.

We observed significant variation among populations for the dormant soil seed bank, and for the proportion of dormant seeds (Table 2; Figure 2). The population factor was almost significant for the offspring number $(P=0.052)$, and for the $\lambda(P=0.052$; Table 2). Variation among populations in the studied variables could emanate from genetic differentiation among populations, as already demonstrated in France (Genton et al., 2005; Leiblein-Wild et al., 2014). It can also be the result of a local adaptation to environmental conditions, even if this subject was assessed in another study on the same geographical scale and did not show any adaptation to local climatic data (Ortmans et al., 2016a). Phenotypic variation can also be attributable to variability in seed lots collected in the field (Ortmans et al., 2016b). Further research is needed to understand the drivers of population variation in the species (Chun et al., 2010).

The seed bank size was variable across the plots, probably because of the spatial heterogeneity of the seed rain (Rabinowitz \& Rapp, 1980). While created in a single seed rain, the seed bank was relatively important, with $306( \pm 51)$ viable seeds $\cdot \mathrm{m}^{-2}$ on average. In comparison, Fumanal et al. (2008b) showed that the soil seed bank of long-established and unmanaged populations in France can vary from 536 to 4,477 seeds $\cdot \mathrm{m}^{-2}$ depending on populations. The seed bank created in our field was smaller, although in 
a comparable range. These observations reinforce the idea of an invasion potential to the north of France. In order to prevent the creation of an important seed bank and the population anchorage for years, the early detection of the newly established populations is of major importance, in order to make the eradication possible. To be complete, the eradication actions have to include the depletion of the soil seed bank. Several good practices can be applied to reach this objective. For example, interventions that stimulate weed germination during intercropping such as a stale seedbed or a stubble ploughing, will promote germinations and thus soil seed bank exhaustion (Infloweb, 2016). It is also advisable to avoid cultivating frequently and successively easy invasible crops (e.g. sunflowers or soya), to limit the production of new seeds. Plowing the plot should also be avoided because it buries the seeds that can therefore remain viable for a long time (Baskin \& Baskin, 1980).

To the best of our knowledge, there are no available data about finite growth rates of A.artemisiifolia invasive populations. It is therefore difficult to evaluate if the finite growth rate we measured in our field is uncommonly high, or not. The $\lambda$ calculated in this study is related to recently introduced populations that are based on transplanted plants. The results should therefore be handled with caution. Nevertheless, the density of the offspring reached 1,020 \pm 70 plants $\cdot \mathrm{m}^{-2}$. This number is about ten times higher than the density of plants that Fumanal et al. (2008b) recorded in invasive populations occurring in agricultural habitats of France. Since this density was formed in a single year from a maximum of 6 plants by plot, the finite growth rate of our population thus appears quite important. If the populations were allowed to reproduce for another year, it is probable that the $\lambda$ would have been closer to 1 , given the already high density of plants observed the second year.

The regional climatic data have shown that the considered years, although relatively similar, were slightly outside the range of temperatures and precipitations that the region normally undergoes. While regrettable from the perspective of having representative conditions of the local climate, this special year of 2013 highlights that even in drier and colder conditions, the species is still able to successfully establish populations north of its current range. This is very interesting because colder conditions are expected to limit the species distribution area (Allard, 1943; Chapman etal.,2014). In 2014, the warmer temperatures likely favored the offspring growth. Since growing conditions were different between 2013 and 2014 due to the larger number of growing plants, it is difficult to assess the gain from the warmer temperatures. Although not negligible, the $0.9^{\circ} \mathrm{C}$ positive difference with the 15 -year average is relatively low, especially in the context of global warming that is expected to lead to a larger temperature increase (Stocker et al., 2013).

\section{CONCLUSIONS}

This work showed that when introduced into an agricultural habitat of Belgium, A. artemisiifolia was able to establish populations with an important finite growth rate. Despite the current rarity of the species in the agricultural fields of Belgium, the growth of the species does not appear to be limited in this habitat. Because of the links between the species' invasion and the sunflower cultivation, great caution has to be exercised if this production extends northwards. North to the current invaded range, awareness actions in the agricultural sector should be raised to avoid the repeated occurrence of the species in the fields remaining unnoticed, and to allow control measures to be initiated in the early stage of the species' establishment.

\section{Acknowledgements}

The authors thank the Unité Mixte de Recherche (UMR) 1347 Agroécologie from the Institut National de Recherche Agronomique of France that collected the seeds. The authors are also grateful to the Fonds de la Recherche dans l'Industrie et dans l'Agriculture (FRIA) for funding this study.

\section{Bibliography}

Agreste - Ministère de l'agriculture de l'agroalimentaire et de la forêt, 2010. Enquête sur les principales grandes cultures, http://agreste.agriculture.gouv.fr/IMG/file/ dossier8_cultures_panorama.pdf, (09/02/2017).

Alexander J.M. \& Edwards P.J., 2010. Limits to the niche and range margins of alien species. Oikos, 119(9), 13771386.

Allard H.A., 1943. The North American ragweeds and their occurrence in other parts of the world. Science, 98, 292294.

Baskin J. \& Baskin C., 1980. Ecophysiology of secondary dormancy in seeds of Ambrosia artemisiifolia. Ecology, 61, 475-480.

Bassett I.J. \& Crompton C.W., 1975. The biology of Canadian weeds: 11. Ambrosia artemisiifolia L. and A. psilostachya DC. Can. J. Plant Sci., 55(2), 463-476.

Blumenthal D. \& Jordan N., 2001. Weeds in field margins: a spatially explicit simulation analysis of Canada thistle population dynamics. Weed Sci., 49(4), 509-519.

Bohren C., 2006. Ambrosia artemisiifolia L. - in Switzerland: concerted action to prevent further spreading. Nachrichtenbl. Dtsch. Pflanzenschutzdienstes, 58(11), $1-15$. 
Brandes D. \& Nitzsche J., 2007. Ecology, distribution and phytosociology of Ambrosia artemisiifolia L. in Central Europe. Tuexenia, 27, 167-194.

Bullock J.M. et al., 2012. Assessing and controlling the spread and the effects of common ragweed in Europe. Final Report to the European Commission, DG Environment. Wallington, UK: Centre for Ecology and Hydrology.

Cetiom, 2013. Cultiver du tournesol / Techniques d'implantation et réalisation du semis, www.cetiom.fr, (01/01/2016).

Chapman D.S. et al., 2014. Phenology predicts the native and invasive range limits of common ragweed. Global Change Biol., 20(1), 192-202.

Chauvel B., Dessaint F., Cardinal-Legrand C. \& Bretagnolle F., 2006. The historical spread of Ambrosia artemisiifolia L. in France from herbarium records. J. Biogeogr., 33(4), 665-673.

Chollet D., Mircovich C. \& Pilorge E., 1998. La lutte contre l'ambroisie dans les cultures de tournesol. Phytoma, 504, 30-32.

Chollet D., Drieu Y., Molines J. \& Pauget J., 1999. Control of common ragweed (Ambrosia artemisiifolia). Perspect. Agric., 250, 78-82.

Chun Y.J., Fumanal B., Laitung B. \& Bretagnolle F., 2010. Gene flow and population admixture as the primary post-invasion processes in common ragweed (Ambrosia artemisiifolia) populations in France. New Phytol., 185(4), 1100-1107.

Cunze S., Leiblein M.C. \& Tackenberg O., 2013. Range expansion of Ambrosia artemisiifolia in Europe is promoted by climate change. ISRN Ecol., 2013, ID 610126.

Essl F., Dullinger S. \& Kleinbauer I., 2009. Changes in the spatio-temporal patterns and habitat preferences of Ambrosia artemisiifolia during its invasion of Austria. Preslia, 81(2), 119-133.

Essl F. et al., 2015. Biological flora of the British isles: Ambrosia artemisiifolia. J. Ecol., 103(4), 10691098.

Fried G., Petit S., Dessaint F. \& Reboud X., 2009. Arable weed decline in Northern France: crop edges as refugia for weed conservation? Biol. Conserv., 142(1), 238-243.

Fumanal B., Chauvel B., Sabatier A. \& Bretagnolle F., 2007a. Variability and cryptic heteromorphism of Ambrosia artemisiifolia seeds: What consequences for its invasion in France? Ann. Bot., 100(2), 305-313.

Fumanal B., Chauvel B.\& Bretagnolle F., 2007b. Estimation of pollen and seed production of common ragweed in France. Ann. Agric. Environ. Med., 14(2), 233-236.

Fumanal B. et al., 2008a. Can the large ecological amplitude of Ambrosia artemisiifolia explain its invasive success in France? Weed Res., 48(4), 349-359.

Fumanal B., Gaudot I. \& Bretagnolle F., 2008b. Seed-bank dynamics in the invasive plant, Ambrosia artemisiifolia L. Seed Sci. Res., 18(2), 101-114.
Genton B.J., Shykoff J.A. \& Giraud T., 2005. High genetic diversity in French invasive populations of common ragweed, Ambrosia artemisiifolia, as a result of multiple sources of introduction. Mol. Ecol., 14(14), 4275-4285.

Gioria M., Pyšek P. \& Moravcová L., 2012. Soil seed banks in plant invasions: promoting species invasiveness and long-term impact on plant community dynamics. Preslia, 84(2), 327-350.

Guillemin J.P. \& Chauvel B., 2011. Effects of the seed weight and burial depth on the seed behavior of common ragweed (Ambrosia artemisiifolia). Weed Biol. Manage., 11(4), 217-223.

Hargreaves A.L., Samis K.E. \& Eckert C.G., 2014. Are species' range limits simply niche limits writ large? A review of transplant experiments beyond the range. Am. Nat., 183(2), 157-173.

Heckel M.E., 1906. Sur l'Ambrosia artemisiifolia L. et sa naturalisation en France. Bull. Soc. Bot. Fr., 53(8), 600620.

Hutchinson G.E., 1957. Concluding remarks. Cold Spring Harb. Symp. Quant. Biol., 22, 415-427.

Infloweb, 2016. L'ambroisie à feuilles d'armoise, http:// www.infloweb.fr/ambroisie-a-feuilles-darmoise, (08/08/2016).

Jouffret P., Labalette F., Thibierge J. \& George V., 2011. Atouts et besoins en innovations du tournesol pour une agriculture durable. Innovations Agron., 14, 1-17.

Kazinczi G. et al., 2008. Common ragweed (Ambrosia artemisiifolia): a review with special regards to the results in Hungary. I. Taxonomy, origin and distribution, morphology, life cycle and reproduction strategy. Herbologia, 9(1), 55-91.

Lambinon J., Delvosalle L.\& Duvigneaud J., 2004. Nouvelle flore de Belgique, du Grand-Duché de Luxembourg, du Nord de la France et des régions voisines. Meise, Belgique : Jardin botanique national de Belgique.

Leiblein-Wild M.C. \& Tackenberg O., 2014. Phenotypic variation of 38 European Ambrosia artemisiffolia populations measured in a common garden experiment. Biol. Invasions, 16, 2003-2015.

Leiblein-Wild M.C., Kaviani R. \& Tackenberg O., 2014. Germination and seedling frost tolerance differ between the native and invasive range in common ragweed. Oecologia, 174, 739-750.

Leiblein-Wild M.C., Steinkamp J., Hickler T. \& Tackenberg O., 2016. Modelling the potential distribution, net primary production and phenology of common ragweed with a physiological model. J. Biogeogr., 43(3), 544-554.

Leskovšek R., Eler K., Batič F. \& Simončič A., 2012. The influence of nitrogen, water and competition on the vegetative and reproductive growth of common ragweed (Ambrosia artemisiifolia L.). Plant Ecol., 213(5), 769-781.

Mack R.N., 1981. Invasion of Bromus tectorum L. into Western North America: an ecological chronicle. AgroEcosystems, 7(2), 145-165. 
Martin P. \& Lambinon J., 2008. Ambrosia artemisiifolia L., l'ambroisie annuelle, en Belgique. Émergence d'une xénophyte et incidence potentielle en santé publique. Nat. Mosana, 61(2), 31-46.

Monty A. \& Mahy G., 2009. Évolution des traits d'histoire de vie lors des invasions végétales. Biotechnol. Agron. Soc. Environ., 13, 449-458.

Monty A., Bizoux J.P., Escarré J. \& Mahy G., 2013. Rapid plant invasion in distinct climates involves different sources of phenotypic variation. PLoS One, 8, e55627.

Ortmans W., Mahy G., Chauvel B. \& Monty A., 2016 a. Performance variation of common ragweed (Ambrosia artemisiifolia L.) across invasion levels in Western Europe. Flora, 220, 134-141.

Ortmans W., Mahy G. \& Monty A., 2016b. Effects of seed traits variation on seedling performance of the invasive weed, Ambrosia artemisiifolia L. Acta Oecologica, 71, 39-46.

Ozaslan C. et al., 2016. Common ragweed: an emerging threat for sunflower production and human health in Turkey. Weed Biol. Manage., 16(1), 42-55.

Pinke G., Karácsony P., Czúcz B. \& Botta-Dukát Z., 2011. Environmental and land-use variables determining the abundance of Ambrosia artemisiifolia in arable fields in Hungary. Preslia, 83(2), 219-235.

Pinke G., Karácsony P., Botta-Dukát Z. \& Czúcz B., 2013. Relating Ambrosia artemisiifolia and other weeds to the management of Hungarian sunflower crops. J. Pest Sci., 86(3), 621-631.

Rabinowitz D. \& Rapp J.K., 1980. Seed rain in a North American tall grass prairie. J. Appl. Ecol., 17(3), 793802.

Richardson D.M. et al., 2000. Naturalization and invasion of alien plants: concepts and definitions. Divers. Distrib., 6(2), 93-107.

Royal Meteorological Institute of Belgium, 2015. Weather in Belgium, http://www.meteo.be, (01/01/2015).

Sarmiento L., Abadín J., González-Prieto S. \& Carballas T., 2012. Assessing and modeling the role of the native legume Lupinus meridanus in fertility restoration in a heterogeneous mountain environment of the tropical Andes. Agric. Ecosyst. Environ., 159, 29-39.

Sexton J., McIntyre P., Angert A. \& Rice K., 2009. Evolution and ecology of species range limits. Annu. Rev. Ecol. Evol. Syst., 40(1), 415-436.

Sibly R.M. \& Hone J., 2002. Population growth rate and its determinants: an overview. Philos. Trans. R. Soc., Ser. B, 357(1425), 1153-1170.

Skálová H. et al., 2015. Effect of temperature and nutrients on the growth and development of seedlings of an invasive plant. AoB Plants, 7(1), 1-8.

Skjøth C.A., Sikoparija B., Jäger S. \& EAN-Network, 2013. Pollen sources. In: Sofiev M. \& Bergmann K.C., eds. Allergenic pollen. Dordrecht, The Netherlands: Springer, 9-27.

Smith M. et al., 2013. Common ragweed: a threat to environmental health in Europe. Environ. Int., 61, 115126.

Sosnoskie L.M., Luschei E.C. \& Fanning M.A., 2007. Field margin weed-species diversity in relation to landscape attributes and adjacent land use. Weed Sci., 55(2), 129136.

Stanton-Geddes J., Tiffin P. \& Shaw R.G., 2012. Role of climate and competitors in limiting fitness across range edges of an annual plant. Ecology, 93(7), 1604-1613.

Stocker T.F. et al., 2013. IPCC, 2013: climate change 2013: the physical science basis. Contribution of working group I to the fifth assessment report of the intergovernmental panel on climate change. Cambridge, UK: Cambridge University Press.

Storkey J. et al., 2014. A process-based approach to predicting the effect of climate change on the distribution of an invasive allergenic plant in Europe. PLoS One, 9(2), 1-7.

Verloove F., 2006. Catalogue of neophytes in Belgium (1800-2005). Meise, Belgique : National Botanic Garden of Belgium, 1-89.

(66 ref.) 